\title{
Anatomical and Immunohistochemical Evaluation of Colorectal Cancer
}

\author{
DELIA HINGANU1', CRISTINEL IONEL STAN*, CORINA CIUPILAN², ALEXANDRU GRIGOROVICI², VIRGIL BULIMAR², \\ LUCIA CORINA DIMA COZMA ${ }^{3}$, MARIUS VALERIU HINGANU ${ }^{1}$ \\ ${ }^{1}$ Grigore T. Popa University of Medicine and Pharmacy, lassi, Romania, Faculty of Medicine, I-st Morpho-Functional Sciences \\ Department, 16 University Str., 700115, Iasi, Romania \\ ${ }^{2}$ Grigore T. Popa University of Medicine and Pharmacy, Faculty of Medicine, I-st Surgical Department, 16 University Str., 16, \\ 700115, lasi, Romania \\ ${ }^{3}$ Grigore T. Popa University of Medicine and Pharmacy, Department of Internal Medicine, 16 Universitatii Str., 700115, Iasi, \\ Romania
}

\begin{abstract}
Colorectal cancer is a malignant disease with high morbidity and mortality. Ki-67 is a marker of cell proliferation associated with a low survival in colorectal cancer patients. Its expression is increased in patients with Dukes C or D colorectal cancer versus those in stage $A$ or $B$. The purpose of the study is to evaluate the immunohistochemical expression of the Ki-67 marker in colorectal adenocarcinomas. The study was performed on a group of 28 patients diagnosed with rectal cancer. We made the histopathological and immunohistochemical evaluation of patients in the study group. The evaluation was performed on the sections stained with hematoxylin-eosin, and for mucinous forms, on sections stained with alcian blue. The topography of the Ki-67 reaction is strictly nuclear, evident in areas with intense proliferative activity. In cases with a strong positive response to Ki-67, the prognosis is worse, with invasion of the perirectal tissues and metastases. The lack of Ki-67 expression in nearby neoplastic tissues suggests that cancerous tissue proliferates in a pathway that it is not correlated with adjacent tissues. The Ki-67 could be useful in the prognosis of patients with colorectal cancer.
\end{abstract}

Keywords: colorectal cancer, Ki-67 immunohistochemical expression, prognosis

Colorectal cancer is a malignant disease with high morbidity and mortality. Neoplastic growth is characterized by uncontrolled proliferation well above the apoptosis rate [1], as well as loss of cell differentiation. For this point of view a neoplasm means a cell growth disorder evidenced by excessive cellular proliferation. Determination of this proliferation can be used in the positive diagnosis and prognosis of neoplastic lesions, and from this point of view, Ki67 is a valuable marker because is not influenced by other comorbidities such as melitus diabetes, cardiovascular disorders, congenital malformations $[2,3]$. Overexpression of this marker may suggest a disturbance of cell division, resulting in the appearance of an intenselygrowing tumor. The marker is also used to determine the degree of aggressiveness and the metastatic tumoral potential $[4,5]$.

The mechanisms by which Ki-67 is involved in cell cycle control are not fully elucidated, but there is a hypothesis that increased values of Ki-67 would act by inhibiting the cell cycle by inducing cellular self-stabilization $[6,7]$.

Immunohistochemical markers CD-34 and Ki-67 appeared relatively recent in the studies. Both markers are sensitive to the assessment of tumor aggressiveness. In normal tissues are very low expressed, and abundant in tumoral tissues. Neoangiogenesis refers to the growth of new capillary vessels from those that already exist. These vessels are strictly orientated to the tumor. This phenomenon is necessary for the tumoral metastasis and, if it does not occur, it is not realized; there are studies on important batches of patients [8-12] showing a relation of determinism between microvascular density and metastatic risk. The expression of these markers is correlated, in the same studies with the patients prognosis, being directly proportional to it. The same was observed in breast cancer, stomach cancer and brain cancer.
The data show that expressions of CD-34, Ki-67 markers are inversely proportional to the degree of tumor histologic differentiation and with tumor staging depending by degree of local extension. At the same time, it is widely accepted that angiogenesis processes have a determining role in the metastasis process and patient prognosis by fascial tunnels organized arround bloodvessels [13]. These two immunohistochemical markers are of high sensitivity and precision, but, however, their expression can not play the role of organ diagnosis because they can not localize the tumor [14].

A 6-month, serial evaluation can play the role of a marker of cancer progression or regression and signifies a new tool in assessing the prognosis of these tumors.

The purpose of the study is to evaluate the immunohistochemical expression of the Ki-67 marker in colorectal adenocarcinomas. Intratumoral concentrations of the Ki-67 antigen are correlated with the tumor proliferation rate and thus the prognosis of the patients.

\section{Experimental part}

Materials and methods

The study was performed on a group of 28 patients diagnosed with rectal cancer. We made the histopathological and immunohistochemical evaluation of patients in the study group. The evaluation was performed on the sections stained with hematoxylin-eosin, and for mucinous forms, on sections stained with Alcian blue. We selected the cases for the immunohistochemical examination, the techniques being applied to low differentiated colorectal carcinomas. Ki-67 is expressed throughout the cell cycle except for the G0 phase, which is why Ki-67's intratumor concentration values correlate with the tumor proliferation rate and thus the prognosis of the patients. 
The nuclear accumulation of the Ki-67 protein was assessed semi-quantitatively: negative (-) which means lack of coloration or presence in less than half of the cells and positive $(+)$ which means the presence of nuclear staining in over $50 \%$ of tumor cells. In turn, the positive response was assessed low positive, moderately positive and strongly positive $(+,++$ and +++$)$.

\section{Results and discussions}

Most of the studied cases were moderate and low differentiated colorectal adenocarcinomas (G2 and G3). Approximately $60 \%$ were in advanced stages (T3), with perirectal adipose tissue invasion.

In G2 adenocarcinomas (fig.1), tumor cells delineate glandular, irregular cavities sometimes with papillary excrescences of different shapes and sizes. The nuclei are large, elongated, hypercromatic, placed on 3-4 layers that occupy the entire thickness of the epithelium. There are areas of ulceration and infection with the presence of stromal inflammatory infiltrates.

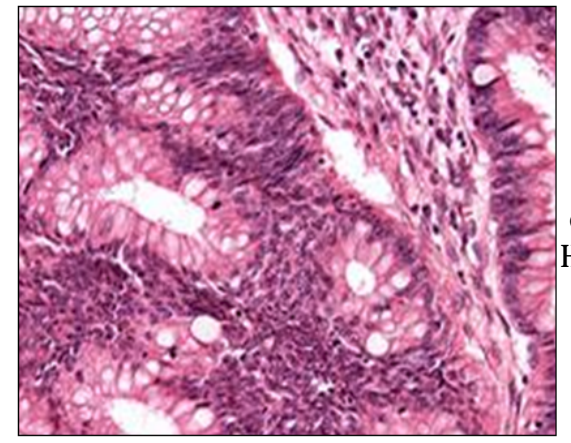

Fig. 1. Moderately differentiated colorectal carcinoma. $H \& E$ staining, ob. $x 40$.

In G3 adenocarcinomas, tumor cells are usually small with hyperchromic nuclei. The stromal volume is increased, there are frequent ulceration areas, the stromal inflammatory infiltrate being abundant (fig. 2).

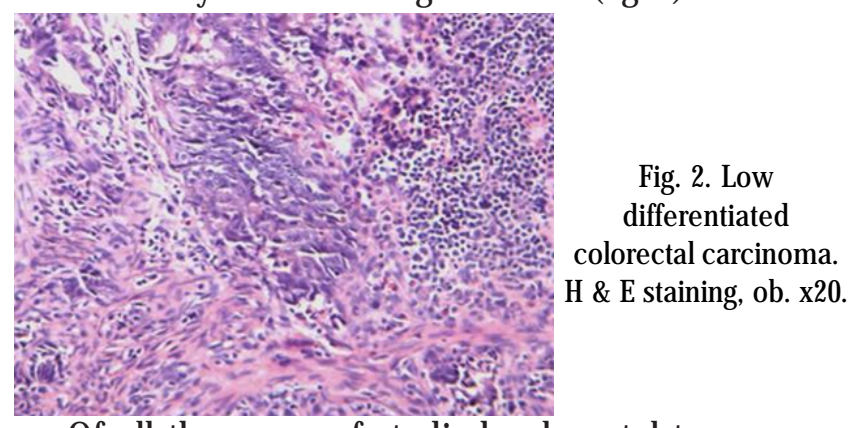

Of all the cases of studied colorectal tumors, we considered mucinous carcinomas the cases where the mucinous component represented more than $30 \%$ (fig. 3).

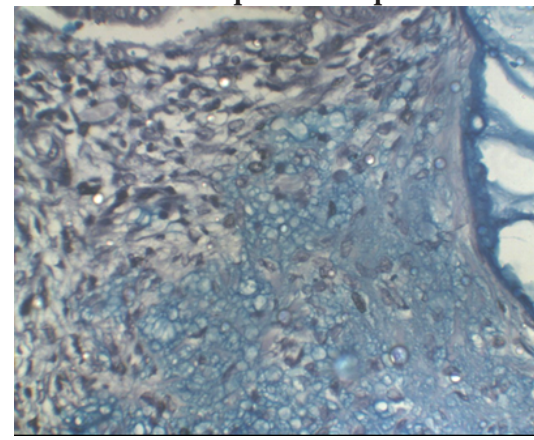

Fig. 3. Low differentiated colorectal carcinoma. Blue Alcian staining, ob. $\mathrm{x} 40$.

Immunohistochemical exam in sections stained for Ki67 has shown that the topography of reaction is strictly nuclear (fig. 4-6), but we could not accurately identify the nuclear localization depending on the division stage. In the tumor there are Ki-67 poor stained areas, probably due to the completion of phase (interphase) and degradation of nuclear staining.

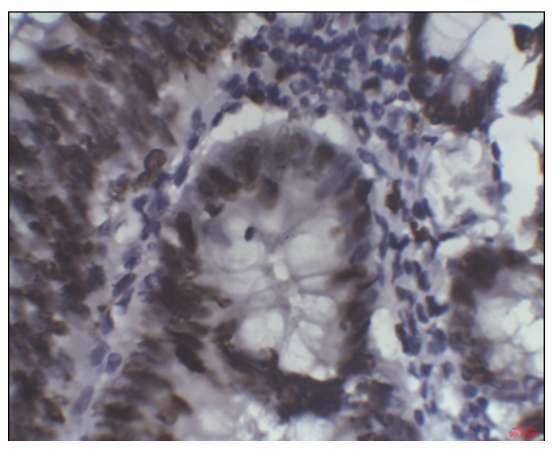

Fig. 4. Strong nuclear reaction of Ki-67 on sections of colorectal cancer $(+++)$. Ob. X60.

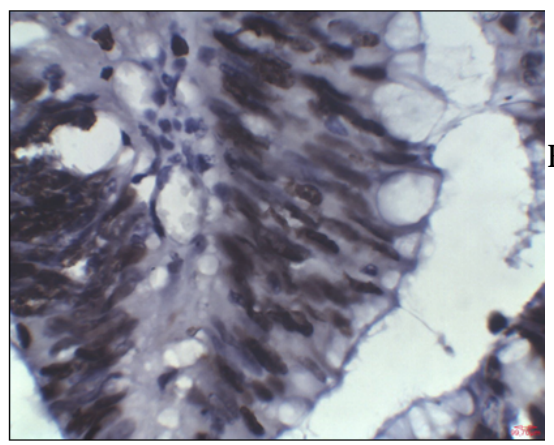

ig. 5. Nuclear Reaction of Ki-67 in the Cells of a colorectal cancer. Ob. X60

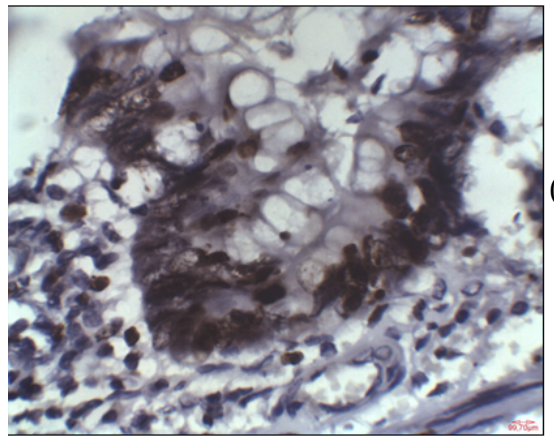

Fig. 6. Intense nuclear +++ ) reaction of $\mathrm{Ki}-67$ on sections of colorectal cancer.

The lack of expression of studied markers in neighboring non-tumor tissues, including Ki-67, suggests that cancerous tissue proliferates in a pathway that is not correlated with adjacent tissues.

In cases with a strong positive response to $\mathrm{Ki}-67(+++)$, prognosis is worse, with invasion of the perirectal tissues, regional lymph nodes and metastases. In these situations there is a direct correlation between the expression and accumulation of the Ki-67 protein and the local, regional or distant extension.

We have not noticed any correlation between the intensity of the reaction and the age and gender of the patient or the exact location of the primitive tumor.

Ki-67, marker of cell proliferation is associated with a low prognosis in colorectal cancer patients. Its expression is increased in patients with Dukes C or D colorectal cancer versus those in stage $\mathrm{A}$ or $\mathrm{B}$. The $\mathrm{Ki}-67$ along with other clinical-pathologic markers could be useful in the prognosis of patients with colorectal cancer.

The growth rate of cancer cells depends on their proliferative activity and cell death rate. Researchers [15] evaluated the expressions of Ki-67, PCNA, MCM in 55 patients diagnosed with colorectal carcinomas and showed that the expressions of the three antibodies are directly correlated with the presence of metastatic lymph nodes but are independent of the age and location of the tumor. It can be concluded that their positive expressions in the mass of the main tumor are directly proportional to pathological stage and histological differentiation gradient.

Neoplastic growth is characterized by uncontrolled proliferation well above the cell death rate, as well as loss 
of cell differentiation. For this reason a neoplasm means a cell growth disorder evidenced by excessive cellular proliferation. Determination of this proliferation can be used in the positive diagnosis and prognosis of neoplastic lesions, and from this point of view, Ki67 is a valuable tool. Exaggerated expression of this marker may suggest a disruption in the regularity of cell division, resulting in the appearance of an intensely-growing tumor.

The Ki67 marker is also used to determine the degree of aggressiveness and the metastatic potential of the tumor.

The Ki-67 monoclonal antibody [16] recognizes an antigen located in cell nuclei in all cell cycle phases except $\mathrm{G}$. The Ki-67 staining method is simple and can be used as a technique to estimate the proliferative activity, as a prognostic marker $[17,18]$ as well as a screening test in individuals with high risk.

The value of this protein's expression has a normal limit in the free mucosa, being somewhat higher in adenomas, and the maxima in adenocarcinomas [19-21].

Researchers found a correlation between the histological degree of malignancy and the depth of tumor infiltration in the wall [22]. Determination of Ki-67 may subdivide a group of patients with similar clinical symptoms into diagnostic and prognostic subgroups.

Since 1988, it has been shown that the immunohistochemical determination of Ki-67 may have clinical application in the selection of patients with colorectal cancer who may benefit from radiotherapy and/or chemotherapy, particularly those with unresectable or locally recurrent tumors [23-28].

Research on colorectal carcinomas using immunohistochemical techniques with Ki-67 protein is simple and relatively easy to apply. The results are reproducible using the MIB 1 antibody with which excellent stains can be obtained, even on the classically fixed paraffin blocks [2935]. Ki-67 expression is high in non-mucosal adenocarcinomas, highly or moderate differentiated, and is low in those that are low differentiated with mucin secretion. This last type of tumor corresponds to an advanced Dukes stage. Thus, there is a close association between the histological grade, type and stage of the tumor.

\section{Conclusions}

Increased expression of the Ki-67 marker is generally associated with a low prognosis of survival, especially in undifferentiated or low differentiated cases of colorectal carcinomas. The Ki-67 along with other clinical-pathologic markers could be useful in the prognosis of patients with colorectal cancer.

\section{References}

1.DANCIU M., LUNGULEAC T., GRIGORESCU C. Rom J Morphol Embryol., 56, no. 2, 2015, p. 545.

2.LUPASCU F.G., AVRAM I., AVRAM L., CONSTANTIN S.M., STAN C.I., LUPUSORU E.C., SAVA A., PROFIRE L. FARMACIA, 65, no. 4, 2017, p. 508.

3.ROMANEC, C., PACURAR, M., DECUSARA, M., SCUTARIU, M.M., HINGANU, D., HINGANU, M.V., CIUPILAN, C., Rev Chim (Bucharest), 69, no. 4, 2018, p. 1002.

4.HÎNGANU M.V., HÎNGANU D., FRANCU L.L. Rom J Morphol Embryol, 54, no.3, 2013, p. 561.

5.HINGANU D., EVAI., STAN C., HINGANU M.V. RomJ Morphol Embryol, 57, no. 1, 2016, p. 161.

6.MCLEOD H.L., MURRAY G.I. Br J Cancer, 79, 1999, p.191.

7.JANKOWSKI J., SAMPLINER R., KERR D., FONG Y. Gastrointestinal Oncology: A Clinical Multidisciplinary Team Approach. Blackwell Publishing, 2008.
8.MIETTINEN M., SOBIN L.H., LASOTA J . Am J Surg Pathol, 29, 2005, p. 522.

9.MA Y-L., PENG P., ZHANG W.J., LIU L., HUANG H.L. Med Oncol, 27, 2010, p. 304.

10.NIETO Y., WOODS J., NAWAZ F., et al. Br J Cancer, 97, 2007, p. 391. 11.DA SILVA B.B., PIRES C.G., DOS SANTOS A.R., et al. Gynecol Obstet Invest, 67, 2008, p. 103.

12.LI Z., ZHAO X., BAI S., et al. Mol Cell Proteomics, 7, 2008, p.1810. 13.HINGANU D., STAN C.I., TARANU T., HINGANU M.V. Rom J Morphol Embryol., 58, no.4, 2017, p. 1327.

14.HINGANU, D., HINGANU, M.V., BULIMAR, V., ANDRONI,C D., Rev. Chim. (Bucharest), 69, no.2, 2018, p. 371.

15.KATARZYNA G.S-U, EWA S., ANDRZEJ K. Anticancer Res, 28, 2008, p. 451.

16.SALAHORU, P., GHICIUC, C.M., GRIGORESCU, C., HINGANU, M.V., LUPUSORU, C.E. Rev.Chim (Bucharest), 69, no.7, 2018, p. 2251.

17.MULLERAT J., DEROIDE F., WINSLET M.C.. Anticancer Res, 23, 2003, p. 2995.

18.0SHIMA C.T.F., IRIYA K., FORONES N.M. Neoplasma, 52, no.5, 2005, p. 420.

19.SALEH H.A., JACKSON H., KHATIB G., BANERJ EE M. Pathol Oncol Res, 5, 1999p. 273

20.HINGANU, D., HINGANU, M.V., MIHALCEANU, E., CALIN, A.M., PANGAL, A., COSTACHESCU, G., ROMILA, A., Rev. Chim. (Bucharest), 69, no. 2, 2018, p. 714.

21.PETRIS A., CIMPOESU D., COSTACHE I., ROTARIU I. REVISTA ROMANA DE BIOETICA, 9, no. 2, 2011, p. 99

22.DZIEEGIEL P., FORGACZ J., SUDER E., SUROWIAK P., KORNAFEL J., ZABEL M. Histol Histopathol,18, 2003 p, 401.

23.SHEPHERD N.A., RICHMAN P.I., ENGLAND J. J Pathol, 155, no.3, 1988, p. 213.

24.IONESCU C.A., VLADAREANU S., PLES L., DIMITRIU M.C.T., FURAU G.O., VLADESCU T.C., CALIN A.M., OPRESCU N.D. ROMANIAN JOURNAL OF MORPHOLOGY AND EMBRYOLOGY, 58, no.1, 2017, p. 219.

25.GRIGORIU, R., CALIN, A.M., ARBUNE, M., MIHALCEANU, E., ONOFRIESCU, M., IONESCU, C.,Rev. Chim. (Bucharest), 67, no.2, 2016, p. 366.

26.GATU, A., VELICESCU, C., GRIGOROVICI, A., DANILA, R., MUNTEAN, V., MOGOS, SI., MOGOS, V., VULPOI, C., PREDA, C., BRANISTEANU, D. ACTA ENDOCRINOLOGICA-BUCHAREST. 13, no.4, 2017, p.441.DOI: 10.4183/aeb.2017.441

27.COBZEANU, B.M., IRIMICIUC, S., VAIDEANU, D., GRIGOROVICI, A., POPA, O., Mat. Plast., 54, no.3, 2017, p.531.

28.GRIGOROVICI, A., CHERCIU, M.S., POPESCU, C.M., APOSTOL, D.G.C. , PREDA, C., CALIN, A., AELENEI, P. FARMACIA, 65, no.1, 2017, p.29.

29.UZMA N., NAGI A.H., WAQAS S. J. Ayub Med Coll Abbottabad, 20, no.5, 2008, p. 44.

30.HINGANU M.V., COZMA R.S., CIOCHINA P., SCUTARIU I.A., ASIMIONOAIEI-SIMIONESCU C., HINGANU D., Rom J Morphol Embryol, 58, no. 4, 2017, p. 1365.

31.COZMA S., DIMA-COZMA L.C., GHICIUC C.M., PASQUALI V., SAPONARO A., PATACCHIOLI F.R. BRAZILIAN J OURNAL OF MEDICAL AND BIOLOGICAL RESEARCH, 50, no.2, 2017, Article Number: e5577, DOI: 10.1590/1414-431X20165577

32.HINGANU, D, SCUTARIU, M.M., HINGANU, M.V. ANNALS OF ANATOMYANATOMISCHER ANZEIGER, 218, 2018, p.271. https://doi.org/10.1016/ j.aanat.2018.04.009

33.COSTACHE, I.I., AL NAMAT, R., MITU, F., CIOCOIU, M., AURSULESEI, V., MITU, O., COSTACHE, A.D., MARCU, D., BUBURUZ, A.M. Rev. Chim. (Bucharest), 68, no. 12, 2017, p. 2967.

34.COSTACHE I.I., UNGUREANU M.C., ILIESCU D., PETRIS A., BOTNARIU G. Rev Med Chir Soc Med Nat lasi, 119, no. 1, 2015, p.18. 35.HINGANU MV, SALAHORU P, HINGANU D. Rev Med Chir Soc Med Nat lasi, 122, no.3, 2018, p. 522.

$\overline{\text { Manuscript received: } 29.08 .2018}$ 